$\underline{\text { Review Article }}$

\title{
MEDICINAL VALUES OF PUTRANJIVA ROXBURGHII-A REVIEW
}

\author{
SUPRIYA B. ${ }^{1}$, KEERTHANA VIJAYAKUMAR ${ }^{1}$, NAMBIRAJAN SUBRAMANIAN², DHARMENDIRA KUMAR \\ MAHENDRADAS ${ }^{*}$
}

${ }^{1}$ Department of Chemical Engineering, St. Joseph's College of Engineering, Chennai 600113, 2Department of Applied Science and Technology, AC Tech Campus, Anna University, Chennai 600025

Email: drmdkumar@gmail.com

Received: 22 May 2017, Revised and Accepted: 22 Jul 2017

\begin{abstract}
The evolving economic concerns and the depletion of natural sources motivate the researchers to look for various alternatives. We started utilizing the bio resources like bio-diesel that is substituted over Petro-diesel. As the needs increasing day by day, it is our responsibility to not to deplete all the resources available now and hence not making the future generation in a great risk. So the idea is to find new sources that we can utilize and to also try to utilize the natural resources around us in a useful manner. In a recent trend, there are more technologies available for utilizing bioresources in an effective manner. One such kind of bio-resource we can utilize is Putranjiva roxburghii. The ultimate aim of this review paper is to create a limelight on the medicinal values of Putranjiva plant. This current study explains the research works done so far with Putranjiva plant in a detailed manner and also to create awareness on growing Putranjiva plant all over the world. The plant material can be utilized as Anti-oxidant, febrifuge and for anti-inflammatory activities, as biofuel, as an herbal preservative, as an Antioxidant agent and as Trypsin inhibitor. The commercial, as well as medicinal values of Putranjiva, are so attractive, that encourages the authors to write a review over this excellent plant material.
\end{abstract}

Keywords: Putranjiva roxburghii, Urban waste, Bio-oil, Preservative, Tripsin Inhibitor, Antioxidant, Anti-inflammatory, Antipyretic, Medicinal values

(C) 2017 The Authors. Published by Innovare Academic Sciences Pvt Ltd. This is an open access article under the CC BY license (http://creativecommons.org/licenses/by/4.0/) DOI: http://dx.doi.org/10.22159/ijcpr.2017v9i5.22160

\section{INTRODUCTION}

Putranjiva roxburghii belongs to euphorbiaceae family that grown abundantly in Asian tropical regions. The plant can be utilised in a number of ways but is still unnoticed as the likes of some famous plant materials like Eucalyptus, Jatropha etc. The famous botanist Roxburgh recognized this plant and accordingly the plant is named as Putranjiva roxburghii [1]. Putranjiva roxburghii belongs to the family Euphorbiaceae. It is also locally called as Drypetes roxburghii, "Pra Kham Kai" or "Ma Kham Kai". It is widely grown all over Asia, particularly in Indochina, India, Nepal, Thailand, Bangladesh, Indochina, Myanmar and Sri Lanka [2]. Putranjiva roxburghii is known for its medicinal qualities, grown all over India. Leaves are normally procreant, bitter, refrigerant and astringent. The leaves are handy in treating of illness, phlegm, skin ailment, aridity and are also helpful in curing rheumatism [3]. The leaf extracts and bio-oil extracted from seeds are mostly utilized in Ayurveda, herbal and Unani medications.

Its leaves and fruits are conventionally used for freeing muscle sprain and curing arthralgia in Thai medicine and the total plant issued to treat sickness and haemorrhoids. Women munch the nuts of Putranjiva orally to influence the birth of a male kid [4]. Two triterpenoids and four triterpenoids were extracted from the shaft bark of the plant $[5,6]$. Adding to this, a triterpene acid and a biflavonoid were also isolated from the alcoholic extract of $P$. roxburghii leaves $[7,8]$. So Putranjiva Roxburghii plant is utilized as an active healing plant and also used to separate some organic chemicals from the leaves and shaft bark of Putranjiva.

Putranjiva is an evergreen tree of Euphorbiaceae family found in tropical parts of India.

Leaves are oblong, simple, shiny, shady green distantly rough. Fruits are spheroidal drupes, seed generally one. Kernelyielding glycosides, glucojiaputin, glucocochlearin, glucoputranjivin, and glucocleomin normally comprises a vital oil with the mustard odour of isothiocyanate [8]. The leaves are procreant and refrigerant which are useful in treating fever, catarrh and sterility. Seeds are fresh and sour. It is ophthalmic emetic, anti-seditious, diuretic and aphrodisiac. It has been used for many conventional health applications such as treatment of mouth and stomach ulcers, hot swellings, small pox and also useful in burning sensation, ophthalmopathy, hyper emesis, elephantiasis, impairment, strangury, azoospermia, usual termination and infertility [6, 11]. Putranjiva roxburghii Wall is commonly called by names Kuduru in Telugu and in Hindi as Putijia belongs to the family Euphorbiaceae grows abundantly in khammam forests of Andhra Pradesh [12]

It is used by tribes in treating a number of health problems [13]. The research was done with a view to separate the ethanolic extract from the P. roxburghii to investigate and to confirm the anti-incitive and antioxidant effects of the ethanolic extract from the leaves and shaft bark of P. roxburghii using dissimilar pharmacological activity simulations in mice. Leaves, fruits and stones of fruits are given in coldness and infections, also in sore affections. Rosaries, made of firm gravels of the berry, are placed over the roll neck of children to secure them from sicknesses [14].

Putranjiva roxburghii grows abundantly in the tropical parts of Asia. The kernel has a sturdy smell with a yield of 0.5 percent. The oil has 2 butyl isothiocyanates and isopropyl as the prime components and 2 methyl-butyl isothiocyanates in a very little amount. In additional, glucoside and glucocleomin are also found in the seed (kernels). The glucoside pattern in the seeds has also been reported to be in roots and shoots. The fruitlet paste comprises a large amount of mannitol and little amount of a saponin glucoside with alkaloid which is also found to be in the stones of the seed case. It is examined that P. roxburghii oil protected the peanut seeds for six months as it has an extreme toxicity against insects and fungi without exhibiting any contrary effect on seed dispersion, sapling growth and general health of plants. So the bio-oil is an effective herbal preservative for peanut seeds against spoilage by fungi and insects while kept in stowage [15]. An ethnobotanical survey taken at Karandamalai, (Southern Eastern Ghats) in Tamil Nadu, a rural area colonized by tribes, revealed the potent application of stalk bark of Putranjiva combined with leaves of Pterospermum suberifolium healing broken bones [16].

In a recent study, change in the oil and fatty acids composition of different aged P. roxburghii seeds was investigated. Oleic and linoleic acids were found to be the major compounds [17]. The ether extract dose from Putranjiva vulnerably produced analgesic activity for squirming in mice induced by acetic acid. At the dose range of 400 $\mathrm{mg} / \mathrm{kg}$, the extract considerably reduced fever caused by yeast in rats 
[18]. Anaesthetic and CNS sedative property of methanol extract of P. roxburghii Wall seeds were examined in a rat model. In the anodyne activity, the reaction time enhanced significantly for the extract and standard groups. The locomotive activity count in the extract and the standard group was significantly reduced when related to other groups [19]. The inhibiting capacity of methanol extract from P. roxburghii displayed severe activity in ferric reducing assay [20].

\section{Putranjiva roxburghii-taxonomy}

Trees-Normally of 20-22m height having a whitish while being young and dusky grey colour when grown up with straight pores; branches generally pendulous; sprigs are cylindrical and tapering with brown colour, slim and flossy. The Putranjiva tree is shown in (fig. 1).

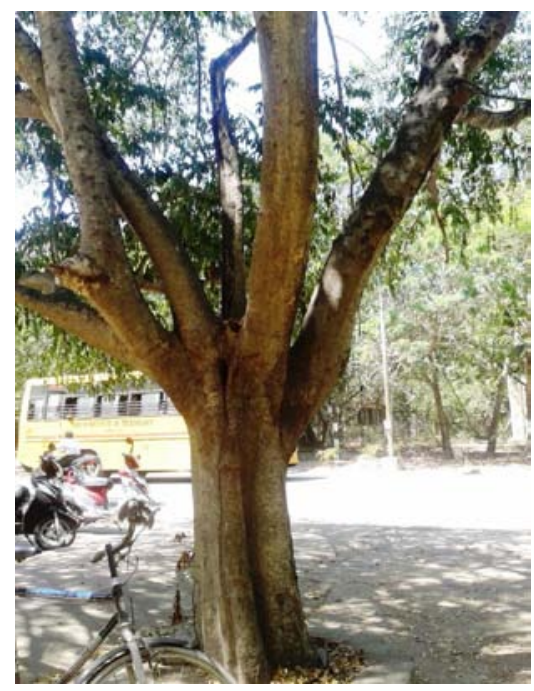

Fig. 1: Putranjiva tree

Leaves-Leaves are alternate; A small leafy outgrowth at the base of the stalk and usually occurring in pairs and shed at an early stage of development, adjacent; leafstalk is of 0.2 to 0.3 inch long, lean, glossy; plates of $2 \times 21$ inch, ovoid and elongated in shape, apex is little sharp, base sloping, dense tip; Jagged like a saw with teeth pointing toward the apex, smooth, dusky green, coriaceous and shining; contiguous6-12 pairs of nerves, featherlike, slim and ascending, lofty, intercostal and reticular. The leaves of Putranjiva are shown in (fig. 2).

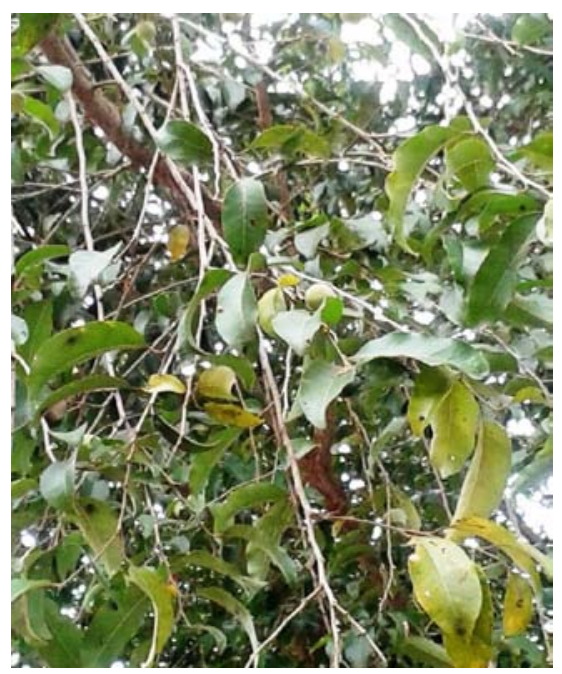

Fig. 2: Putranjiva leaves

Flowers-Flowers having only one type of sexual organ; not hermaphroditic, small, yellow in colour; Male flowers-stalk less, in alar spikes, 2-2.5 mm across; pedicels are of 1.5-3 mm long, sepal is of 3-5, square shaped, puberulent without, cilial, rounded at the apex, overlapping or layered as scales or shingles; stamens having a length of 1.5-2 mm; thick fibrils, more or less cognate towards foot; borne on the stalk is ovate, hirsute; Female flowers-Hermit and alar; pedicle up to $15 \mathrm{~mm}$ long, puberulent; husks shaped like a lance head; petals $2.5 \times 1-1.5 \mathrm{~mm}$, uneven, having elongated form with approximately parallel sides, 3-celled, ovum 2 in each cell; type 3 , dispersal, shielded with thickly tangled strings, often cognate with broad plump stigma; stigma semilunar-shaped, glandular.

Fruit-Stone fruit with a single seed of 1.18 inch. Oval shaped and ellipsoidal, enclosed with thickly tangled strings; having a hard crust or shell; A small stalk bearing a single flower of an inflorescence 0.21inch long [21]. The fruits of Putranjiva trees are shown in (fig. 3).

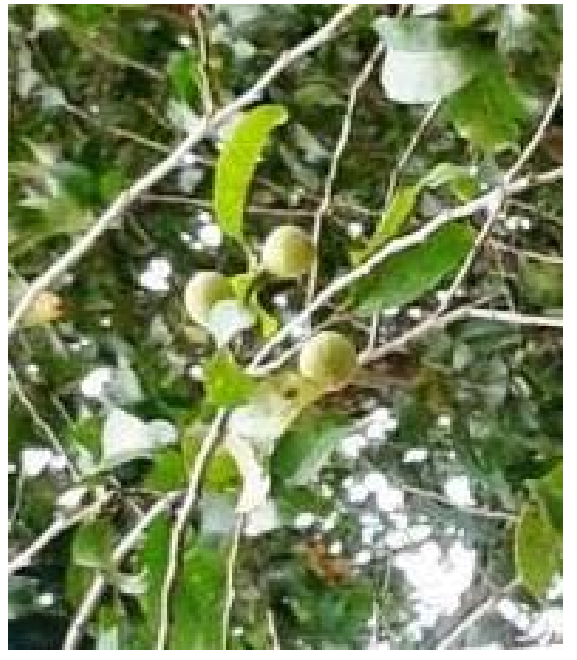

Fig. 3: Putranjiva fruits

\section{Utilizing putranjiva in a number of ways}

\section{As herbal preservative}

Other than utilizing Putranjiva oil as a biofuel, we can use it as an effective herbal preservative. A research work was carried out for preserving 200 grams of sissoo seeds. Putranjiva oil was used in the research work as a preservative. The Putranjiva oil protected the sissoo seeds for about six months without revealing any side effects. It did not exhibit any contrary influence on seed incubation, sapling growth. It did not reveal any bad effect on the plant's health and the structure of the plant while growing. So it is obvious that the seed kernel oil of Putranjiva displayed a great performance as a protective layer for sissoo seeds, thus it shown a great antifungal activity against the fungi and protected the seeds from insects too. Putranjiva oil was also tested as an antifungal agent in another research work. In that work, several fungi separated from root samples were taken for studying the fungi-toxic nature of the oil. All the experiments were done twice and had five replicates.

While studying the toxicity at 500 ppm, Putranjiva oil exhibited perfect toxicity in inhibiting both the test fungi completely whereas other oils at the same concentrations exhibit a very lesser amount of fungi-toxic nature. Putranjiva seed oil revealed an excellent repellence when tested against the insect called Bruchuspisorum, in a small dosage of $0.02 \mathrm{ml}$ while the same amount of other oils failed to exhibit the same repellence. At $400 \mathrm{ppm}$, the seed oil of Putranjiva repressed the mycelial growth of ten fungi. It was also noted in that study that Putraniva oil inhibited the growth of all ten discs of diameter $5 \mathrm{~mm}$ and of single mycelia disc of $11 \mathrm{~mm}$ diameter which was the maximum observed in the study. Hence the antifungal latent of the oil seemed to have severe inoculant density. Even the high temperature of autoclaving at $100{ }^{\circ} \mathrm{C}$ for six months had no effect on the antifungal nature of the oil [25]. 
In another research work, it was reported that, at a minimum inhibitory concentration of $400 \mathrm{ppm}$, the seed oil of Putranjiva exhibited severe toxicity and noted to be fungicidal. The peanut seeds held in the $250 \mathrm{ml}$ container (200 grams) were completely protected for $6 \mathrm{mo}^{*}$ by the Putranjiva oil of amount 0.25 and $0.38 \mathrm{ml}$. There were no side effects caused on the growth of seedlings, germination of seeds and also the eidonomy of plants by this preservation method [7, 8]. So at even low Minimal inhibitory concentration, with long shell life, the Putranjiva seed oil revealed a high potent herbal preserving tendency for managing the insect attacks on plants after their harvest.

\section{As trypsin inhibitor}

A high potent, stable inhibitor was made from the seeds of Putranjiva by cleansing it to obtain homogeneousness with the help of anion and cation exchange chromatography. The 'Sodium dodecyl sulphatepolyacrylamide gel electrophoresis' analysis under dipping condition revealed that protein with single polypeptide chain with a molar mass of 34kilodaltons approx. The cleansed inhibitor repressed dense trypsin in 1:1 mole ratio. The inhibitor reserved the repressing activity above a broad range of $\mathrm{pH} 2-12$ at the temperature range of $20-80{ }^{\circ} \mathrm{C}$ in a Dithiothreitol amount up to $100 \mathrm{mmol}$. The inhibiting nature of the stable inhibitor was lost at the temperature range on or above 90 ${ }^{\circ} \mathrm{C}$. The structural stability of the inhibitor was confirmed at high temperatures while doing the cluster of determinants (CD) studies. The backbone fold of polypeptide was reserved even up to $80^{\circ} \mathrm{C}$. Thus the inhibitor expressed a momentous sameness to the protease inhibitors those having the nature of inhibiting the enzymes, those are degrading proteins. Hence Putranjiva seeds can express the same nature of protease inhibitors and can be used as effective kunitz-type inhibitors [26].

\section{Cytotoxic activity}

The cytotoxic nature of methanol extract obtained from the seeds of Putranjiva roxburghii was investigated in order to screen the treatment role of the plant against some deadly diseases like cancer. The basic phytochemical testing of methanol extract from Putranjiva seeds showed the existence of alkaloids, steroids, flavonoids, saponins and glycosides. The extract exhibited cytotoxic nature with Lethal concentration 50 (concentration in water having 50\% chance of causing death to aquatic life) of $427.74 \mu \mathrm{g} / \mathrm{ml}$ in Artemia (Brine shrimp) lethality assay and found to be toxic. This lethality testing method signifies a cheap and easy bioassay that tests the bio-activity of some plant extracts. This research work confirms that the extracts of Putranjiva seeds have high cytotoxicity and antitumour property [27].

\section{Utilizing putranjiva leaves}

The sensitive responses in mice made by the effects of the ether extract from Putranjiva leaves were tested with the help of three (writhing, formalin and hot plate) tests. The anti-instigative actions were also inspected by means of paw oedema in rat. In the writhing test, different dosages of ether extracts formed pain-relieving activity in squirming tempted by acetic acid in the mouse. In hot plate test, no major effect was noted. In the formalin test, ether extract of dosage $400 \mathrm{mg} / \mathrm{kg}$ efficiently stopped the tramping activity in rats and declined illness caused by yeast. There was a slight inhibitory action observed against the paw oedema caused by carrageen an in rats. The extract blocked oedema in ear triggered by croton oil in an effective manner. The anus oedema induced by Croton tiglium was hindered by either extract at the high dose of $800 \mathrm{mg} / \mathrm{kg}$ in rats. The results showed that the ether extract of $\mathrm{P}$. roxburghii leaves exhibit very effective anaesthetic, febrifuge and antiinstigative activities [28].

\section{Antifungal activities of putranjiva}

Putranjiva roxburghii plays an important, assuring role in the traditional medical systems of Unani and Ayurvedic which provide complete health by means of herbal medicines in the east. Especially the leaves are reported to have more medicinal values [29]. In another research work, the refinement, classification and replicating of aninnovative 12 kiloDaltons 'Heterodimeric protein' belonging to 2S albumin family of $\mathrm{P}$. roxburghii seeds were studied. The result showed that the seeds has a range of potentially consumable activities like RNase, DNase, anti-fungal and ex-vivo translational repressive nature [30].

\section{Hypoglycaemic activity}

In utilizing glucose, due to perturbation, some neurological disorders like retinopathy, neuropathy, angiopathy and nephropathy were caused. For these severe diabetic disorders, the most common reason is Diabetes mellitus. It is an endocrine disorder, which damages glucose metabolic equilibrium. Putranjiva roxburghii has been known for its antidiabetic properties by many researchers. The antidiabetic quality of Putranjiva roxburghii was studied in a research work which encouraged diabetes in anomaly rat models by using alloxan monohydrate $\left(\mathrm{C}_{4} \mathrm{H}_{2} \mathrm{~N}_{2} \mathrm{O}_{4}\right)$. The study was undertaken to display the hypoglycemic quality of ethanol extracts of Putranjiva roxburghii leaves. Effective anti-hyperglycemic activity was revealed with the ethanolic extract dosages of 250 and $500 \mathrm{mg} / \mathrm{kg}$ on the fourth, seventh and tenth day after treatment. Blood glucose level reduced even at a dosage level of $100 \mathrm{mg} / \mathrm{kg}$, but the results were found to be relatively minor. The results exhibited that the ethanol extract has momentous anti-hyperglycemic effect in an investigational model of diabetes mellitus. It was concluded in this work that, the ethanolic extract of Putranjiva roxburghii has valuable effects in reducing the blood glucose levels. Further pharmacological and biological experiments will clearly expose the mechanism which is responsible for the action and it will be more useful in protruding this plant as a healing target in diabetes research [31].

\section{Other uses}

It is reported that Biodiesel from Putranjiva oil, blended or pure, has exposed very acceptable results as an alternate fuel for diesel engines. It has been concluded that the diesel engine can run very satisfactorily using $100 \%$ of biodiesel at the timing of 450 bTDC timing and compression ratio of 20. All diesel engines can be operated with $100 \%$ biodiesel obtained from Putranijiva as a primary force without any alteration of the engine [22].

The non-edible urban waste source Putranjiva is regarded that it can be utilized in any diesel engine. The non-edible Putranjiva roxburghii oil can be used as an alternate diesel fuel for diesel engine without any alteration of the engine in the agricultural zones during fuel emergencies. The $30 \%$ blends of pure Putranjiva oil and diesel reduce the emissions such as NOx, smoke, $\mathrm{CO}$ and particulates etc. The performance such as BTE (brake thermal efficiency) and BSFC are comparable to diesel fuel. Above 30\% blend, abovementioned qualities show lesser excellence.

Hence it is obvious that Putranjiva oil blend can be replaced in place of fossil-diesel for forcing the diesel engine suitably with decreasing emissions that are very beneficial in case of environmental impact on the human beings. ${ }^{1}$ Kernels are consumed orally by sterile ladies to influence the formation and endorsed with the birth of a boy [24].

\section{CONCLUSION}

This review exhibits the complete utilization of the potentially economic important tree Putranjiva in a detailed manner. It highlights the medicinal values as well the commercial usage of Putranjiva like Bio-fuel. Putranjiva can be used as Biofuel, Herbal preservative, Trypsin Inhibitor, Antifungal, Antipyretic and Antidiabetic agent. Further researches can be taken over this plant especially in its stem bark as the extracts may have an extraordinary medicinal or commercial value within. It is concluded that, instead of growing some decorative trees as garden trees, we can plant Putranjiva roxburghii as a garden plant which can be utilised in a number of ways. Putranjiva is as gigantic as banyan tree having the qualities of also being a good gardening tree that can provide a dense shadow and cool air.

\section{CONFLICT OF INTERESTS}

\section{Declare none}

\section{REFERENCES}

1. Haldar SK, Ghosh BB, Nag A. Studies on the comparison of performance and emission characteristics of a diesel engine using three degummed non-edible vegetable oils. Biomass Bioenergy 2009;33:1013-8. 
2. Phuphathanaphong L, Chayamarit K. Flora of thailand euphorbiaceae. Natl Herb Nederland 2006;336:1877-87.

3. Ashok S. The Herbs of Ayurveda, Ashok Sheth, India; 2005

4. Khare CP. Indian medicinal plants: an illustrated dictionary, Springer, New York; 2007.

5. Garg HS, Mitra CR. Putranjiva roxburghii Wall.-II triterpenes of the trunk bark. Phytochemistry 1968;7:2053-5.

6. Sengupta P, Mukherjee J. Terpenoids and related compounds-XI the structure of roxburgholone, a new triterpenoid constituent of putranjiva roxburghii. Tetrahedron 1968;24:6259-64.

7. Garg HS, Mitra CR. Roxburghonic acid-a friedelane triterpenoid keto acid of the leaf of putranjiva roxburghii. Phytochemistry 1971;10:865-9.

8. Garg HS, Mitra CR. Putraflavone, a new biflavonoid from putranjiva roxburghii. Phytochemistry 1971;10:2787-91.

9. Rizk FM. The chemical constituents and economic plants of the Euphorbiaceae. Bot J Linn Soc 1987;94:293-326.

10. Sengupta P, Chakraborty AK, Duffield AM, Durham LJ, Djerassi C. Chemical investigations on putranjiva roxburghii: the structure of a new triterpene, putranjivadione. Tetrahedron 1968;24:1205-13.

11. Varshney AK, Aquil M, Rahman W, Okigawa M, Kawano N. Biflavones from putranjiva roxburghii. Phytochemistry 1973;12:1501.

12. Lakshmi Rajahamsa A, Deepak K, Kesava Rao TK, Pranav Kumar A, Sreenivas Reddy G, Potbhare M. Multi-model confirmatory evaluation of anti-inflammatory, analgesic and antioxidant activities of Putranjiva roxburghii wall. Int J Biomed Adv Res 2013;4:921-32.

13. Padal SP, Chandrasekhar P. Ethnomedicinal use of herb species khammam district, Andhra Pradesh. Int J Innovative Res Dev 2013;2:1287-98.

14. Limbani Rajen K, Bandhiya Hemant M, Dedakia Arjun S, Desai Tusharbindu R, Patel Vishal L, Pandya Devang J. Pharmacognostic and phytochemical evaluation of leaves of putranjiva roxburghii. Int J Comprehensive Pharm 2011;11:1-3.

15. Tripathi NN, Kumar N. Putranjiva roxburghii oil-a potential herbal preservative for peanuts during storage. J Stored Products Res 2007;43:435-42.

16. Kottaimuthu R. Ethnobotany of the valaiyans of karandamalai, dindigul district, Tamil Nadu, India. Ethnobotanical Leaflets 2008;12:195-203.

17. Gangal S, Sharma S, Rauf A. Putranjiva roxburghii seeds: oil content and fatty acid composition during different stages of seed maturity. J Pharm Res 2009;2:1666-8.

18. Reanmongkol W, Noppapan T, Subhadhirasakul S. Antinociceptive, antipyretic, and anti-inflammatory activities of Putranjiva roxburghii Wall. leaf extract in experimental animals. J Natl Med 2009;63:290-6.

19. Sudharshan SJ, Chinmaya A, Valleesha NC, Kekuda TRP, Rajeshwara AN, Murthuza S. Central nervous system (CNS) depressant and analgesic activity of methanolic extract of drypetes roxburghii wall in the experimental animal model. Res J Pharm Technol 2009;2:854-7.

20. Chinmaya A, Sudharshan SJ, Valleesha NC, Kekuda TRP, Rajeshwara AN, Murthuza S, et al. Phytoconstituents and antioxidant activity of drypetes roxburghii wall, cosciniumfenestratum colebr and Nardostachysjatamansi DC. Global J Pharmacol 2009;3:53-8.

21. Hurusawa. Drypetes roxburghii (Wall.). J Fac Sci Univ Tokyo Sect 3. Bot 1954;6:337.

22. Ghosha B, Sandip Kumar Haldar, Ahindra Nag. Synthesis of biodiesel from oils of Jatropha, karanja and putranjiva to utilize in ricardo engine and its performance and emission measurement, proceedings of the 4th BSME-ASME. International Conference on Thermal Engineering 2008. p. 27-9.

23. Haldar SK, Ghosh BB, Nag A. Utilization of unattended putranjiva roxburghii non-edible oil as fuel in a diesel engine. Renewable Energy 2009;34:343-7.

24. Shailja T. Medicinal plants used by tribal inhabitants of sirmour district, Himachal Pradesh. Indian J Sci Res 2011;2:125-7.

25. Narendra Kumar. Fumigant potential of seed kernel oil of putranjiva roxburghii wall against storage pests of seeds of dalbergiasissoo roxb. J Pharm Biol Sci 2014;9:80-9.

26. Navneet Chaudhary S, Chandan Shee, Asimul Islam, Faizan Ahmad, Dinesh Yernool, Pravindra Kumar, et al. Purification and characterization of a trypsin inhibitor from Putranjiva roxburghii seeds. Phytochemistry 2008;69:2120-6.

27. Raghavendra H, Prashith Kekuda T, Valleesha N, Sudharshan S, Chinmaya. Screening for cytotoxic activity of methanol extract of putranjiva roxburghii wall (Euphorbiaceae) Seeds. Pharmacogn J 2010;2:335-7.

28. Wantana Reanmongkol, Tassanee Noppapan, Sanan Subhadhirasakul. Antinociceptive, antipyretic, and antiinflammatory activities of Putranjiva roxburghii Wall. leaf extract in experimental animals. J Nat Med 2009;63:290-6.

29. Madhavi Badole R, Vidya Dighe V. Microscopical and physicochemical investigations of the leaves of putranjiva roxburghii wall. Int J Pharm Sci Res 2012;3:2599-602.

30. Prabhat Pratap Singh Tomar, Navneet Chaudhary. Purification, characterization and cloning of a $2 \mathrm{~S}$ albumin with DNase, RNase and antifungal activities from putranjiva roxburghii. Appl Biochem Biotechnol 2014;174:471-82.

31. Amit Varma, Jain SK, Shashi Alok. Hypoglycemic activity of putranjiva roxburghii wall. inalloxan induced diabetic rats. Int J Pharm Sci Res 2010;1:160-4.

\section{How to cite this article}

- Supriya B, Keerthana Vijayakumar, Nambirajan Subramanian, Dharmendira Kumar Mahendradas. Medicinal values of putranjiva roxburghii-a review. Int J Curr Pharm Res 2017;9(5):5-8. 